\title{
PENGARUH WAKTU EKSTRAKSI TERHADAP MUTU EKSTRAK CAIR RUMPUT LAUT Gracilaria sp. SEBAGAI BAHAN BAKU PUPUK CAIR
}

\author{
Effect of Extraction Time on Quality of Gracilaria sp. Sap as Raw \\ Material for Liquid Fertilizer
}

\author{
Nurhayati $^{1 *}$, Olivia Oktaviani ${ }^{2}$, dan Jamal Basmal ${ }^{1}$ \\ ${ }^{1}$ Balai Besar Riset Pengolahan Produk dan Bioteknologi Kelautan dan Perikanan, \\ JI. KS Tubun Petamburan VI, Slipi, Jakarta, Indonesia \\ ${ }^{2}$ Fakultas Perikanan dan IImu Kelautan dan IImu Kelautan, Universitas Brawijaya, \\ Jl. Veteran, Malang, Jawa Timur \\ *Korespondensi Penulis: n_hay04@yahoo.com
}

Diterima: 13 Desember 2017; Direvisi: 26 Februari 2018; Disetujui: 13 Maret 2018

\begin{abstract}
ABSTRAK
Ekstrak cair rumput laut kini telah banyak digunakan dalam bidang pertanian karena mengandung senyawa penting yang dibutuhkan tanaman. Penelitian ini bertujuan untuk mengetahui pengaruh waktu ekstraksi terhadap mutu ekstrak cair Gracilaria sp. sebagai bahan pupuk cair. Ekstrak cair diekstrak menggunakan larutan $\mathrm{KOH} 0,3 \%$ pada suhu $80{ }^{\circ} \mathrm{C}$ dengan waktu ekstraksi 0, 2, 4, dan 6 jam. Parameter yang diamati yaitu nilai $\mathrm{pH}$, EC (electrical conductivity), TDS (total dissolved solids), viskositas, C-organik, serta kadar unsur hara makro $\mathrm{N}$ dan K. Hasil penelitian menunjukkan bahwa perlakuan optimum untuk menghasilkan ekstrak cair terbaik adalah pada perlakuan waktu ekstraksi selama 2 jam yaitu dengan nilai pH 6,35, EC 4,9 mS/cm,

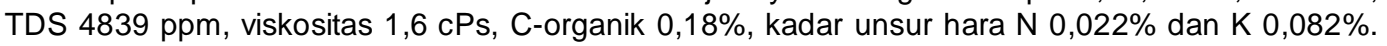

KATA KUNCI : ekstrak cair, rumput laut merah, Gracilaria sp., pupuk cair, waktu ekstraksi

\begin{abstract}
Seaweed sap has now been widely used in agriculture due to the content of essential compounds needed by plants. This study aimed to determine the effect of extraction time on the quality of Gracilaria sp. sap as material for liquid fertilizer. Seaweed sap was extracted using $0.3 \% \mathrm{KOH}$ solution at $80{ }^{\circ} \mathrm{C}$ with various extraction times of $0,2,4$, and 6 hours. The parameters observed were $\mathrm{pH}, \mathrm{EC}$ (electrical conductivity), TDS (total dissolved solids), viscosity, C-organic, and macro nutrient content of $N$ and $K$. The results showed that the optimum treatment was extraction for 2 hours produced sap with $\mathrm{pH}$ value of 6.35 , EC of $4.9 \mathrm{mS} / \mathrm{cm}$, TDS of $4839 \mathrm{ppm}$, viscosity of $1.6 \mathrm{cPs}$, C-organic of $0.18 \%$, nutrient content $N$ of $0.022 \%$ and $K$ of $0.082 \%$.
\end{abstract}

KEYWORDS: sap, red seaweed, Gracilaria sp., liquid fertilizer, extraction time

\section{PENDAHULUAN}

Pupuk cair adalah suatu sediaan cair yang mengandung sejumlah nutrisi yang dibutuhkan untuk pertumbuhan dan perkembangan tanaman. Berdasarkan sumber bahan pembuatnya, pupuk cair terbagi menjadi pupuk kimia (anorganik) dan pupuk organik. Pupuk kimia terbuat dari bahan kimia sintetis sementara pupuk organik berasal dari hewan atau tumbuhan (Simamora \& Salundik, 2005). Kadar nutrisi dan reaksi terhadap tanaman pada pupuk organik umumnya lebih rendah dibandingkan pupuk anorganik.
Adanya kombinasi antara pupuk organik dengan pupuk kimia mungkin dapat mengatasi permasalahan tersebut sehingga dapat saling melengkapi kekurangan unsur-unsur yang diperlukan untuk pertumbuhan dan peningkatan produksi tanaman (Basmal, 2009).

Penggunaan ekstrak cair rumput laut pada bidang pertanian sebagai perangsang pertumbuhan telah banyak diteliti (Carvalho, Castro, Novembre \& Chamma, 2013; Fan, Hodges, Critchley \& Prithiviraj, 2013; Kocira, Swieca, Kocira, Zlotek \& Jakubczyk, 2016; Lola-Luz, Hennequart \& Gaffney, 2014; 
Papenfus, Kulkarni, Stirk, Finnie \& Van Staden, 2013; Zodape et al., 2011). Ekstrak cair rumput laut telah digunakan sebagai pupuk pada akuaponik yaitu kombinasi akuakultur dan hidroponik (Alamsjah \& Prayogo, 2014). Ekstrak cair rumput laut dapat meningkatkan perkecambahan biji dan pertumbuhan tanaman (Kumar, Mohan, Murugeswari \& Muthuswamy, 1993; Rao \& Chatterjee, 2014; Sasikala, Indumathi, Radhika, \& Sasireka, 2016), serta memperbaiki pengaruh dari tekanan abiotik seperti salinitas, suhu ekstrim, defisiensi nutrisi dan kekeringan pada tanaman hortikultura (Battachatyya, Babgohari, Rathor \& Prithiviraj, 2015). Sementara Ezzat et al. (2011) melaporkan bahwa campuran ekstrak rumput laut dengan NPK $50 \%$ dapat meningkatkan kadar pati pada kentang dan mengurangi gula pereduksi. Ekstrak cair juga dapat menjaga tingkat kelembaban tanah, terdegradasi secara alami, tidak beracun atau mengkontaminasi, dan aman terhadap manusia dan hewan (Dhargalkar \& Pereira, 2005).

Ekstrak cair rumput laut mengandung makro nutrien, unsur hara, asam amino serta pemicu pertumbuhan tanaman (Sedayu, Basmal, Utomo, 2013; Thirumaran, Arumugam, Arumugam \& Anantharaman, 2009). Ekstrak cair tersebut terkandung dalam talus rumput laut yang memiliki dinding sel yang kompleks sehingga efisiensi ekstraksi sangat dipengaruhi oleh komposisi pelarut, suhu, dan waktu (Michalak \& Chojnacka, 2014). Basmal et al. (2015) menggunakan $\mathrm{KOH}$ untuk mengeluarkan ekstrak cair dari rumput laut Sargassum sp. Penggunaan alkali dapat mendegradasi lignin, selulosa dan sebagian hemiselulosa yang terkandung dalam rumput laut (Ong, Chuah \& Chew, 2009). Alkali juga dapat menyebabkan rumput laut menjadi mengembang (swelling) sehingga luas permukaan semakin meningkat. Swelling disebabkan oleh signifikasi ikatan ester intermedullar dan pemisahan ikatan hidrogen yang mengikat selulosa, sehingga menyebabkan depolimerisasi selulosa (Fan et al., 1982 dalam Ong et al., 2009). Perlakuan panas yang diterapkan juga dapat menyebabkan pembengkakan lebih lanjut dari rumput laut yang mengakibatkan peningkatan porositas rumput laut sehingga reaksi menjadi lebih optimal. Penelitian ini bertujuan untuk mengetahui pengaruh waktu ekstraksi terhadap mutu ekstrak cair rumput laut Gracilaria sp. sebagai bahan pupuk cair.

\section{BAHAN DAN METODE}

\section{Bahan}

Bahan baku yang digunakan pada penelitian ini adalah rumput laut Glacilariasp. kering yang diperoleh dari pembudidaya di Desa Lontar, Serang. Bahan kimia yang digunakan adalah $\mathrm{KOH}$ teknis yang berperan untuk mengeluarkan ekstrak cair dari rumput laut. Sementara peralatan yang digunakan di antaranya wadah gelas, waterbath, dan spinner.

\section{Metode}

Rumput laut Gracilaria sp. kering disortasi dan dicuci hingga bersih untuk menghilangkan kotoran dan kerang-kerang yang menempel. Selanjutnya, ekstrak cair rumput laut diekstraksi melalui pemanasan dalam larutan $\mathrm{KOH} 0,3 \%(1: 10 \mathrm{~b} / \mathrm{v})$ suhu $80^{\circ} \mathrm{C}$ menggunakan waterbath. Lama waktu ekstraksi divariasikan yaitu untuk jam ke-0 dilakukan selama 5 menit, selanjutnya 2 jam, 4 jam, dan 6 jam. Setelah ekstraksi selesai, dilakukan penyaringan menggunakan kain blacu dengan tujuan memisahkan filtrat dari residunya. Selanjutnya digunakan spinner selama 15 menit untuk memisahkan filtrat yang masih tersisa di dalam residu. Kedua filtrat yang diperoleh ini selanjutnya digabung dan disimpan dalam cold storage hingga analisis dilakukan.

Parameter uji yang dianalisis pada ekstrak cair rumput laut meliputi EC (electrical conductivity) dan TDS (total dissolved solids) menggunakan TDS dan $\mathrm{EC}$ meter (Hold), analisis $\mathrm{pH}$ menggunakan $\mathrm{pH}$ meter Thermo Orion $420 \mathrm{~A}$, viskositas menggunakan Viscometer Brookfield RVDV-II, kadar C-organik menggunakan metode Walkey dan Black (AOAC, 2002), $\mathrm{N}$ total menggunakan metode Kjeldahl (BSN, 2006), $\mathrm{P}$ total $\left(\mathrm{HNO}_{3} /\right.$ Spektrofotometri) dan $\mathrm{K}$ total menggunakan metode $\mathrm{HNO}_{3} / \mathrm{FAAS}$ berdasarkan AOAC (2002).

\section{HASIL DAN PEMBAHASAN}

\section{Nilai pH}

Nilai pH ekstrak cair rumput laut Gracilaria sp. dapat dilihat pada Gambar 1 dengan kisaran nilai antara 5,84-6,78. Nilai pH tertinggi terdapat pada perlakuan 4 jam ekstraksi yaitu sebesar $6,78 \pm 0,10$. Sementara nilai $\mathrm{pH}$ terendah terdapat pada sampel dengan perlakuan 0 jam yaitu sebesar $5,84 \pm 0,70$. Semakin lama waktu kontak antara $\mathrm{KOH}$ dengan ester sulfat dari rumput laut, maka semakin banyak garam sulfat yang terbentuk, di mana garam sulfat bersifat netral sehingga nilai $\mathrm{pH}$ larutan semakin mendekati netral. Pada pupuk cair untuk tanaman hidroponik, kisaran $\mathrm{pH}$ yang dipersyaratkan adalah 5,5-6,5 (Sutiyoso, 2004). Sementara pada pupuk organik cair nilai pH berkisar 4-8 (Peraturan Mentan, No. 2/Pert/ HK.060/2/2006 dalam Suriadikarta \& Setyorini, 2006). Dengan demikian, nilai $\mathrm{pH}$ ekstrak cair rumput laut Gracilaria sp. ini masuk ke dalam standar yang 


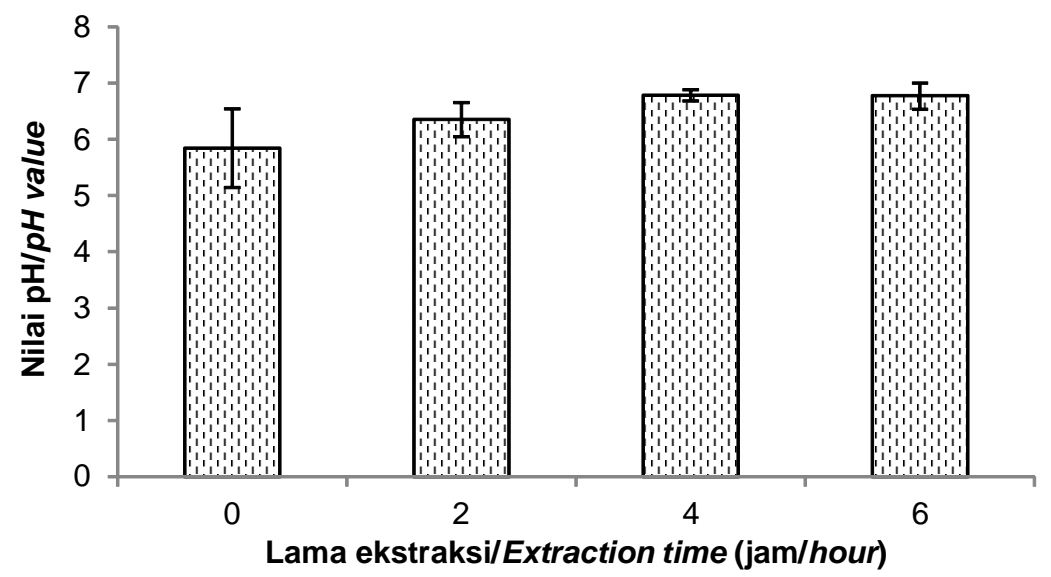

Gambar 1. Nilai pH ekstrak cair Gracilaria sp.

Figure 1. $\mathrm{pH}$ value of sap Gracilaria sp.

dipersyaratkan baik pada pupuk cair untuk budidaya hidroponik maupun sebagai pupuk organik cair berdasarkan standar Permentan.

\section{Nilai EC}

Nilai konduktivitas listrik (electrical conductivity/ EC) menunjukkan konsentrasi ion dalam larutan. Nilai EC ekstrak cair rumput laut Gracilaria sp. dapat dilihat pada Gambar 2. Nilai EC tertinggi terdapat pada

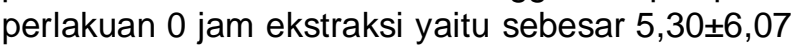
$\mathrm{mS} / \mathrm{cm}$. Sementara nilai EC terendah terdapat pada perlakuan 6 jam ekstraksi yaitu sebesar 2,15 $\pm 1,14$ $\mathrm{mS} / \mathrm{cm}$. Nilai EC tersebut semakin menurun seiring bertambahnya waktu ekstraksi. Semakin lama waktu ekstraksi maka semakin banyak mineral yang terlarut. Namun demikian, agar-agar dan senyawa lain yang terkandung dalam rumput laut juga semakin banyak yang terekstrak. Agar-agar menyebabkan terhambatnya pergerakan ion dalam larutan sehingga nilai EC menjadi semakin rendah. Pada penelitian ini, nilai EC yang dihasilkan relatif tinggi sehingga jika digunakan secara langsung akan menyebabkan tanaman mengalami kejenuhan dalam menyerap hara yang mengakibatkan pertumbuhan menjadi stagnan (Sutiyoso, 2009). Pada nutrisi untuk tanaman hidroponik, nilai EC yang dipersyaratkan untuk sayuran daun yaitu 1,5-2,0 mS/cm (Sutiyoso, 2009). Sementara menurut Suhardiyanto et al. (2009), nilai EC optimal nutrisi yang digunakan pada tomat saat berbunga, berbuah dan panen berturut-turut adalah $1,4 \mathrm{mS} / \mathrm{cm}, 10,2 \mathrm{mS} / \mathrm{cm}$ dan $9,7 \mathrm{mS} / \mathrm{cm}$. Dengan demikian, perlu adanya pengenceran ekstrak cair rumput laut sebelum digunakan.

\section{Nilai TDS}

TDS (total dissolved solids) adalah jumlah padatan terlarut dalam suatu larutan. Pengukuran TDS dan EC sama-sama bertujuan untuk mengetahui konsentrasi unsur hara pada larutan nutrisi. Perbedaannya terletak pada satuan yang digunakan

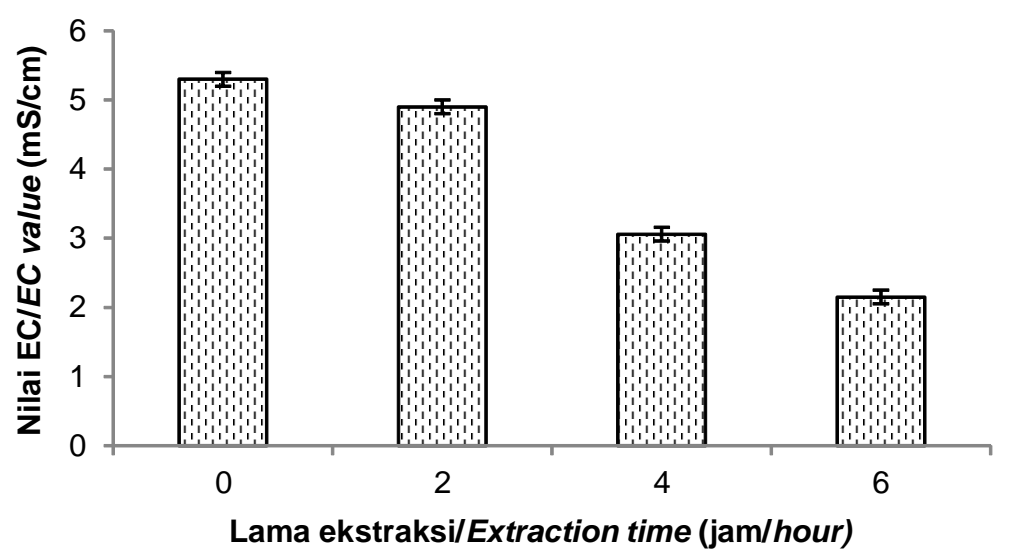

Gambar 2. Nilai EC ekstrak cair Gracilaria sp.

Figure 2. EC value of sap Gracilaria sp. 


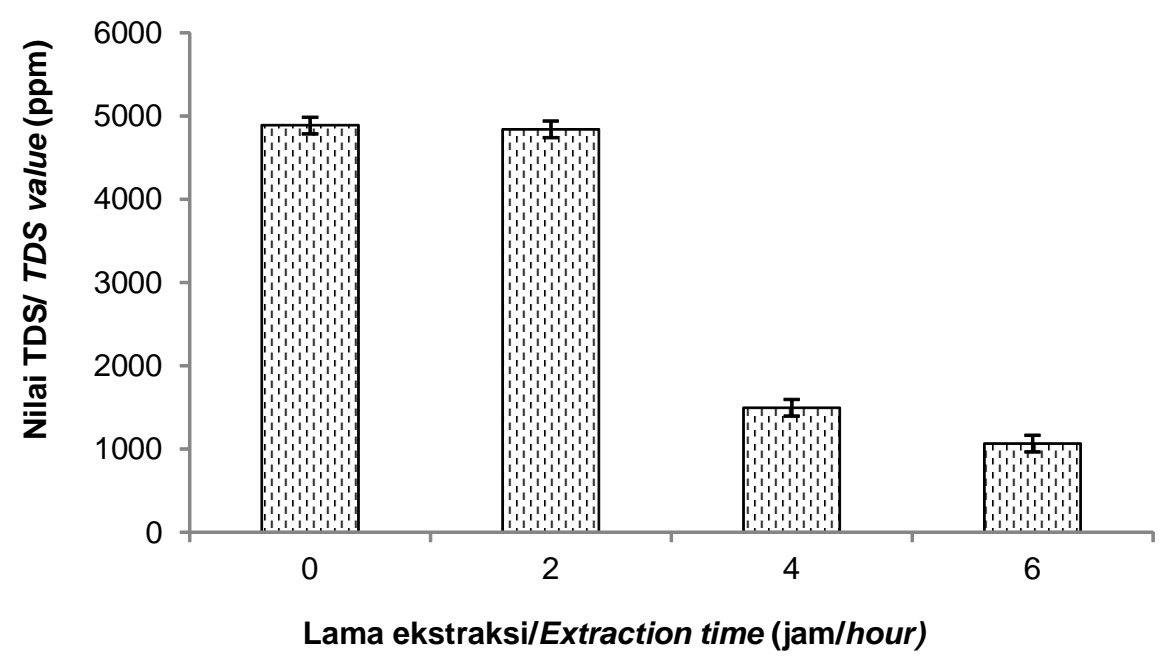

Gambar 3. Nilai TDS ekstrak cair Gracilaria sp.

Figure 3. TDS value of sap Gracilaria $s p$.

serta nilai konversi yang beragam pada TDS sehingga petani lebih cenderung menggunakan nilai EC dibanding TDS. Hasil dari pengujian TDS pada ekstrak cair Gracilariasp. dapat dilihat pada Gambar 3. Sama seperti pola grafik nilai EC pada Gambar 2, nilai TDS juga memperlihatkan bahwa semakin lama ekstraksi dilakukan maka nilai TDS ekstrak cair Gracilaria sp. semakin menurun. Nilai TDS tertinggi terdapat pada perlakuan 0 jam ekstraksi yaitu 4888 ppm, sedangkan nilai TDS terendah diperoleh pada perlakuan 6 jam ekstraksi yaitu sebesar 1067 ppm. Konsentrasi ion total dari larutan nutrisi menentukan pertumbuhan, perkembangan dan produksi tanaman (Steiner, 1961 dalam Trejo-Téllez \& Gómez-Merino, 2012).

\section{Viskositas}

Hasil dari pengujian viskositas ekstrak cair rumput laut Gracilaria sp. dapat dilihat pada Gambar 4. Hasil pengamatan menunjukkan bahwa nilai viskositas tertinggi terdapat pada sampel dengan perlakuan 4 jam ekstraksi yaitu 2,8 $\pm 0,8 \mathrm{cPs}$, sedangkan nilai viskositas terendah terdapat pada sampel dengan perlakuan 2 jam ekstraksi yaitu sebesar $1,4 \pm 0,0 \mathrm{cPs}$. Perbedaan nilai kekentalan ekstrak cair disebabkan pengaruh dari $\mathrm{KOH}$ yang diberikan selama proses ekstraksi. Perendaman menggunakan larutan alkali mampu menarik sebagian besar protein (deproteinase), selulosa dan mineral yang terkandung

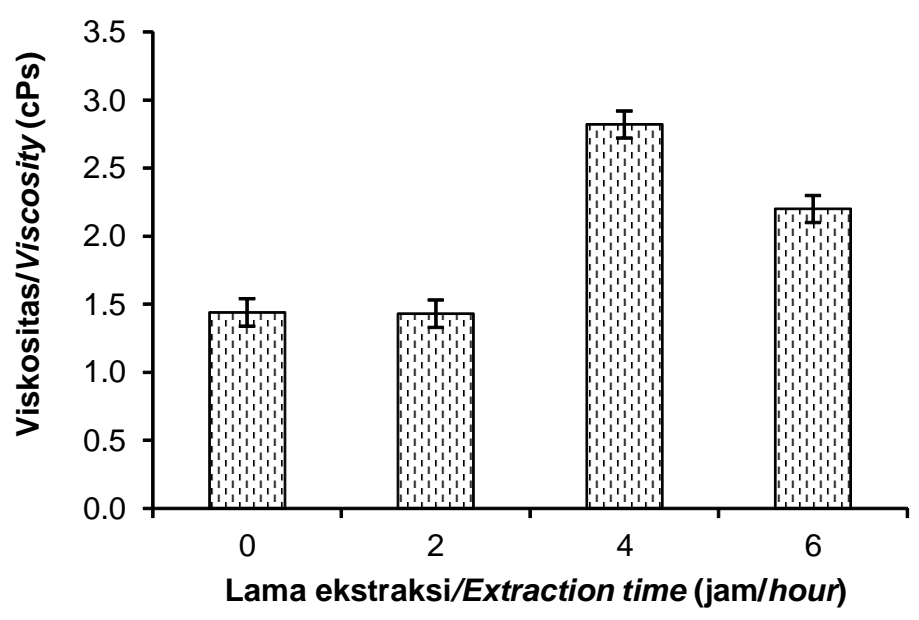

Gambar 4. Nilai viskositas ekstrak cair Gracilaria sp.

Figure 4. Viscosity value of sap Gracilaria sp. 


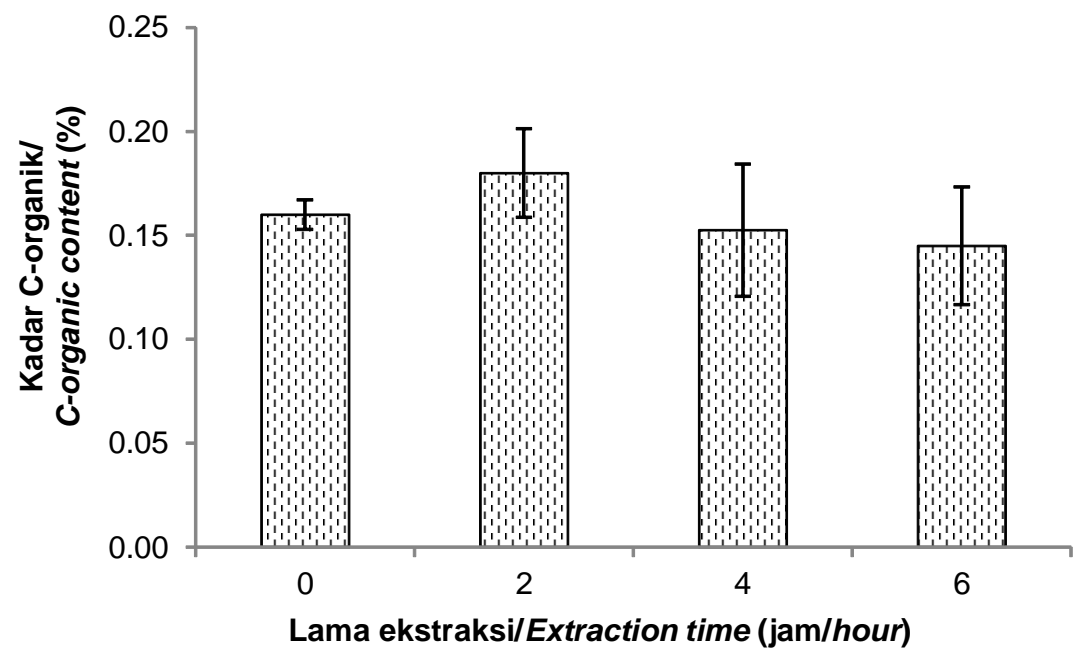

Gambar 5. Kadar C-organik ekstrak cair Gracilaria sp.

Figure 5. C-organic content of sap Gracilaria sp.

dalam rumput laut. Pupuk yang baik memiliki viskositas yang tidak terlalu kental sehingga mudah diserap oleh tanaman. Dengan demikian, dari hasil analisis diketahui bahwa perlakuan terbaik adalah pada ekstrak cair dengan perlakuan waktu ekstraksi 2 jam.

\section{C-organik}

Nilai C-organik digunakan sebagai pembeda antara pupuk organik dengan pupuk anorganik. Kandungan C-organik yang dihasilkan berkisar antara $0,14 \pm 0,01$ $0,17 \pm 0,02 \%$ (Gambar 5). Kandungan C-organik dalam ekstrak cair Gracilaria sp. semakin menurun dengan bertambahnya lama ekstraksi. Berdasarkan standar mutu pupuk organik cair yang di tetapkan oleh
Peraturan Menteri Pertanian No.28/Permentan/ OT.140/2/2009, nilai C-organik yang dipersyaratkan sebesar $\leq 2 \%$. Dari hasil yang diperoleh didapatkan keseluruhan sampel dari 4 perlakuan berada di bawah batas standar mutu yang telah ditentukan. Dengan demikian, ekstrak cair tidak dapat digolongkan sebagai pupuk organik melainkan dapat diklasifikasikan sebagai pembenah tanah organik.

\section{Kandungan Unsur Hara Makro Nitrogen (N)}

Kadar $\mathrm{N}$ tertinggi terdapat pada sampel dengan perlakuan 2 jam ekstraksi yaitu $0,022 \%$. Sementara kadar $\mathrm{N}$ terendah terdapat pada sampel dengan perlakuan 4 jam ekstraksi yaitu sebesar 0,005\%. Dari

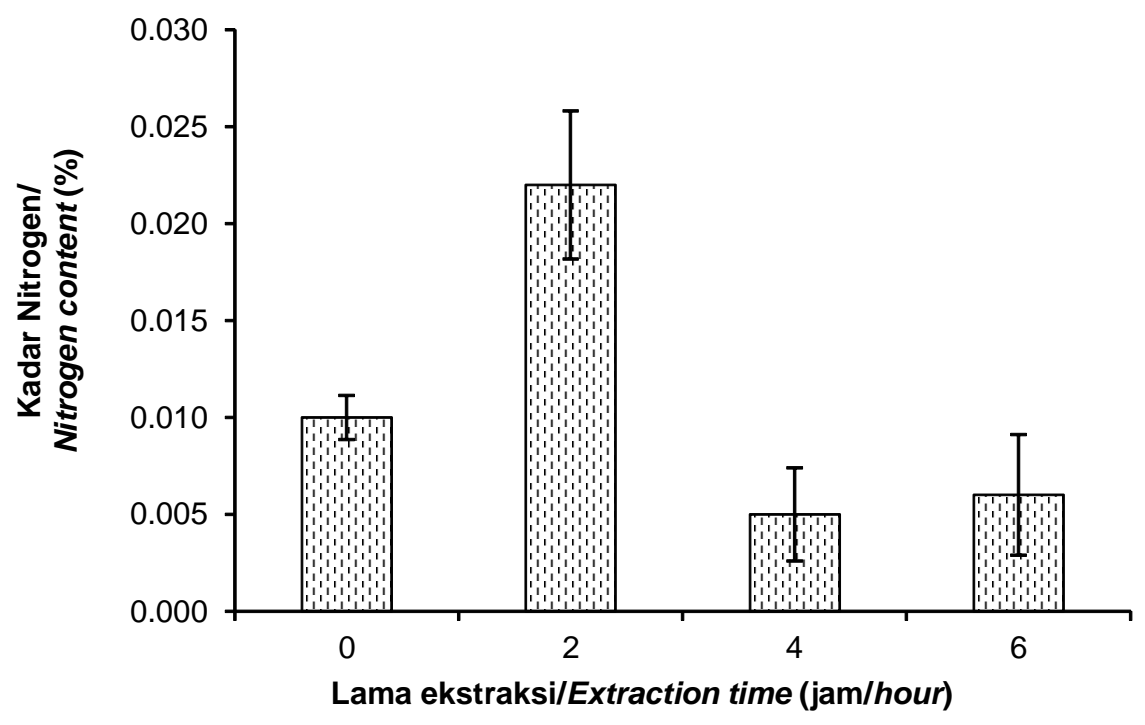

Gambar 6. Kadar Nitrogen (N) ekstrak cair Gracilaria sp.

Figure 6. Nitrogen $(N)$ content of sap Gracilaria sp. 


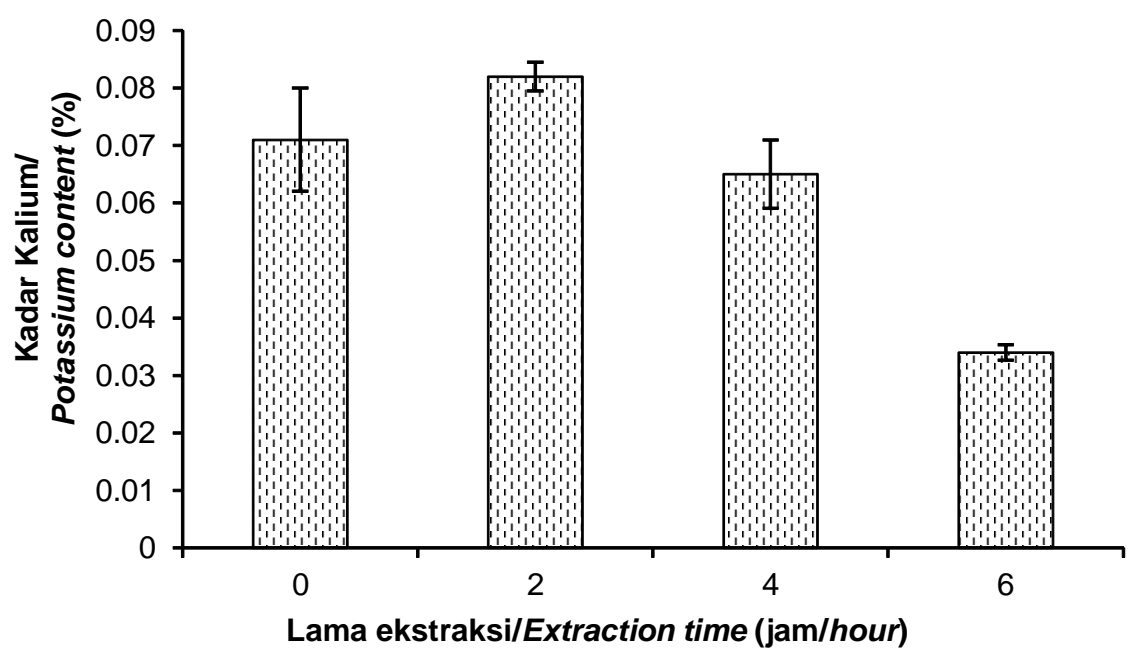

Gambar 7. Kadar kalium (K) ekstrak cair Gracilariasp Figure 7. Pottasium (K) content of sap Gracilaria sp.

hasil ini diketahui bahwa perlakuan terbaik yang menghasilkan kadar $\mathrm{N}$ tertinggi adalah pada perlakuan ekstraksi 2 jam.

Berdasarkan standar mutu pupuk organik cair yang ditetapkan oleh Peraturan Menteri Pertanian No. 28/ Permentan/OT.140/2/2009, nilai $N$ yang dipersyaratkan sebesar $<2 \%$. Hasil yang diperoleh menunjukkan bahwa keseluruhan sampel dari 4 perlakuan memiliki nilai yang jauh di bawah $2 \%$. Kandungan unsur $\mathrm{N}$ yang terdapat pada ekstrak cair Gracilaria sp. masih rendah sehingga dibutuhkan penambahan bahan lainnya untuk meningkatkan unsur hara pupuk. Sementara pada pupuk hidroponik, persyaratan kandungan $\mathrm{N}$ pupuk untuk sayuran daun adalah sebesar $250 \mathrm{ppm}$ atau $0,025 \%$ (Sutiyoso, 2004), sehingga dari hasil yang diperoleh diketahui bahwa perlakuan 2 jam ekstraksi telah mendekati nilai standar pupuk hidroponik.

\section{Kandungan Unsur Hara Makro Kalium (K)}

Berdasarkan Gambar 7 diketahui bahwa kadar kalium tertinggi terdapat pada sampel dengan perlakuan 2 jam ekstraksi yaitu 0,082 $\pm 0,002 \%$. Sementara kadar terendah terdapat pada sampel dengan perlakuan 6 jam ekstraksi yaitu sebesar $0,034 \pm 0,001 \%$. Hasil ini menunjukkan bahwa perlakuan terbaik yang menghasilkan kadar kalium tertinggi adalah perlakuan ekstraksi 2 jam. Kadar kalium yang terukur berasal dari penggunaan $\mathrm{KOH}$ pada saat ekstraksi dan juga kalium yang terkandung dalam rumput laut. Berdasarkan standar mutu pupuk organik cair yang ditetapkan oleh Peraturan Menteri Pertanian No. 28/Permentan/OT.140/2/2009, nilai K yang dipersyaratkan adalah $<2 \%$. Dari hasil yang diperoleh didapatkan keseluruhan sampel dari 4 perlakuan berada di bawah batas standar mutu yang telah ditentukan. Namun, jika ekstrak cair ditujukan sebagai pupuk hidroponik untuk sayuran daun (350 ppm atau 0,035\%), maka perlakuan 6 jam ekstraksi telah mendekati standar, sementara untuk perlakuan lainnya diperlukan adanya pengenceran sehingga dapat memenuhi standar.

\section{KESIMPULAN}

Berdasarkan standar pupuk cair sesuai Peraturan Menteri Pertanian No. 28/Permentan/OT.140/2/2009), ekstrak cair dari rumput laut Gracilaria sp. belum dapat dikategorikan sebagai pupuk karena rendahnya kadar N dan K. Namun berdasarkan karakteristik yang diperoleh dari hasil penelitian, ekstrak cair ini dapat digunakan sebagai pupuk untuk budidaya hidroponik. Perlakuan yang menghasilkan pupuk cair terbaik adalah pada perlakuan ekstraksi selama 2 jam dengan nilai $\mathrm{pH} 6,35$, EC $4,9 \mathrm{mS} / \mathrm{cm}$. TDS $4839 \mathrm{ppm}$, viskositas $1,6 \mathrm{cPs}$, C-organik $0,18 \%$, kadar unsur hara $\mathrm{N} 0,022 \%$, dan $\mathrm{K} 0,082 \%$.

\section{DAFTAR PUSTAKA}

Alamsjah, M.A \& Prayogo. (2014). Mineral nutrient content from Gracilaria sp. waste as biofertilizer on intensive aquaculture with aquaponic system. Journal of Natural Sciences Research, 4(21), 65-74.

Association of Official Agriculture Chemists. (2002). Official Methods of Analysis of AOAC International. Volume 1, p. 2.5-2.37. in Horwitz, W. (Ed.). Agricuture Chemicals, Contaminants, Drugs. AOAC International, Maryland, USA. $17^{\text {th }}$ ed. 
Basmal, J. (2009). Prospek pemanfaatan rumput laut sebagai bahan pupuk organik. Squalen Buletin Pascapanen dan Bioteknologi Kelautan dan Perikanan, 4(1), 1-8.

Basmal, J., Kusumawati, R., \& Utomo, B.S.B. (2015). Mutu sap liquid rumput laut Sargassum yang diekstrak menggunakan kalium hidroksida sebagai bahan pupuk. JPB Kelautan dan Perikanan, 10(2), 143-153.

Battachatyya, D., Babgohari, M. Z., Rathor, P., \& Prithiviraj, D. (2015). Seaweed extracts as biostimulants in holticulture. Scientia Holticulturae, 196, 39-48.

BSN. (2006). SNI 01-2354.4-2006. Cara uji kimia Bagian 4: Penentuan kadar protein dengan metode total nitrogen pada produk perikanan. Jakarta: Badan Standardisasi Nasional.

Carvalho, M.E.A., Castro, P.R.C., Novembre, A.D.C., \& Chamma, H.M.C.P. (2013). Seaweed extract improves the vigor and provides the rapid emergence of dry bean seeds. Am.-Eurasian Agric. Environ. Sci., 13, 1104-1107.

Dhargalkar, V. K. \& Pereira, N. (2005). Seaweed: Promising plant of the millennium. Science and Culture, 71, 60-66.

Ezzat, A. S., Asfour, H. El-S. \& Tolba, M. H. (2011). Improving yield and quality of some new potato varieties in winter plantation using organic stimulators. J. Plant Production, Mansoura Univ., 2(5), 653 - 671.

Fan, D., Hodges, D.M., Critchley, A.T., \& Prithiviraj, B. (2013). A commercial extract of brown macroalga (Ascophyllum nodosum) affects yield and the nutritional quality of spinach in vitro. Commun. Soil Sci. Plant Anal., 44, 1873-1884.

Kocira, A., Swieca, M., Kocira, S., Zlotek, U, \& Jakubczyk, A. (2016). Enhancement of yield, nutritional and nutraceutical properties of two common bean cultivars following the application of seaweed extract (Ecklonia maxima). Saudi Journal of Biological Sciences. https://doi.org/10.1016/j.sjbs.2016.01.039

Kumar, V.V.R., Mohan, R., Murugeswari \& Muthuswamy, M. (1993). Effect of crude and commercial seaweed extracts on seed germination and seedling growth in green gram and black gram. Seaweed Research \& Utilization, 16(1\&2), 23-27.

Lola-Luz, T., Hennequart, F., \& Gaffney, M. (2014). Effect on yield total phenolic, total flavonoid and total isothiocyanate content of two broccoli cultivars (Brassica oleraceae var italica) following the application of a commercial brown seaweed extract (Ascophyllum nodosum). Agric. Food Sci., 23, 2837.

Michalak, I \& K. Chojnacka. (2014). Algal extracts: Technology and advances. Engineering in Life Sciences, 14(6), 581-591.

Ong, L.G.A., Chuah, C. \& Chew, A.L. (2009). Comparison of sodium hydroxide and potassium hydroxide followed by heat treatment on rice straw for cellulase production under solid state fermentation. The Proceeding of 3rd International Conference on Chemical \& Bioprocess Engineering 12th - 14th, Universiti Malaysia Sabah, Kota Kinabalu, Sabah.

Papenfus, H.B., Kulkarni, M.G., Stirk, W.A., Finnie, J.F., \& Van Staden, J. (2013). Effect of a commercial seaweed extract $\left(\right.$ Kelpak $\left.^{\circledR}\right)$ and polyamines on nutrient-deprived (N, P and K) okra seedlings. Sci. Hortic., 151, 142-146.

Peraturan Menteri Pertanian. (2009). Standard Mutu Pupuk Organik Cair (POC). No.28/Permentan/ OT.140/2/2009. Jakarta.

Rao, G.M.N. \& Chatterjee, R. (2014). Effect of Seaweed Liquid Fertilizer from Gracilaria Textorii and Hypnea Musciformis on Seed Germination and Productivity of Some Vegetable Crops. Universal Journal of Plant Science, 2(7), 115-120. DOI: 10.13189/ ujps.2014.020701.

Sasikala, M., Indumathi, E., Radhika, S., \& Sasireka, R. (2016). Effect of seaweed extract (Sargassum tenerrimum) on seed germination and growth of tomato plant (Solanum lycopersicum). International Journal of ChemTech Research CODEN (USA), 9 (9): 285-293.

Sedayu, B.B., Bamal, J., \& Utomo, B.S.B. (2013). Identifikasi hormon pemacu tumbuh ekstrak cairan (SAP) Eucheuma cottonii. Jurnal Pascapanen dan Bioteknologi Kelautan dan Perikanan. 8 (1): 1-8.

Simamora, S., \& Salundik. (2005). Meningkatkan Kualitas Kompos. Jakarta: Agromedia Pustaka.

Suhardiyanto, H., Arif, C., \& Setiawan, B.I. (2009). Optimization of EC values of nutrient solution for tomato fruits quality in hydroponics system using artificial neural network and genetic algorithms. Journal of Mathematical and Fundamental Sciences ITB, 41(1): 38-49.

Suriadikarta, D.A. \& Setyorini, D. (2006). Baku mutu pupuk organik: pupuk organik dan pupuk hayati. Balai Besar Litbang Sumberdaya Lahan Pertanian. Badan Litbang Pertanian

Sutiyoso, Y. (2004). Hidroponik ala Yos. Jakarta: Penebar Swadaya.

Thirumaran, G., Arumugam, M., Arumugam, R. \& Anantharaman, P. (2009). Effect of seaweed liquid fertilizer on growth and pigment concentration of Abelmoschus esculentus (I) medikus. American Eurasian Journal of Agronomy, 2 (2): 57-66.

Trejo-Téllez \& Gómez-Merino. (2012). Nutrient solutions for hydroponic systems. www.Intechopen.com.

Zodape S.T., Abha Gupta, S.C. Bhandari, U.S. Rawat, D.R. Chaudhary, K. Eswaran \& A. Chikara (2011). Foliar application of seaweed sap as biostimulant for enhancement of yield and quality of tomato (Lycopersicon esculentum Mill.). J. of Scientific and Industrial Research, 70, 215-219. 
JPB Kelautan dan Perikanan Vol. 13 No. 1 Tahun 2018: 33-40 